\title{
Validasi School Burnout Inventory versi Bahasa Indonesia
}

\author{
Diniy Hidayatur Rahman* \\ Jurusan Bimbingan dan Konseling, Universitas Negeri Malang \\ Jl. Semarang 5, Malang, Jawa Timur, 65145, Indonesia \\ *Corresponding Author. e-mail: diniy.hidayatur.fip@um.ac.id
}

\begin{abstract}
Abstrak
Burnout akademik merupakan sebuah kondisi yang dapat berdampak negatif pada para pelajar, baik secara akademik, pribadi, maupun sosial. Pencegahan terhadap dampak lanjutan yang tidak diinginkan melalui sebuah identifikasi dini. School Burnout Inventory merupakan salah satu instrumen berbahasa Inggris yang efektif untuk melakukan identifikasi dini. Penelitian ini bertujuan untuk mengetahui validitas dan reliabilitas School Burnout Inventory versi Bahasa Indonesia dalam konteks program sarjana, serta menguji jumlah faktor yang membentuknya. Proses adaptasi School Burnout Inventory dilakukan dengan menerjemahkannya ke dalam Bahasa Indonesia dan menyesuaikannya dengan konteks pendidikan di perguruan tinggi. Uji kesahihan terjemahan oleh ahli bahasa dan pakar dalam bidang burnout. Instrumen yang telah diadaptasi, disebarkan kepada 542 mahasiswa program sarjana (126 laki-laki dan 416 perempuan), yang dipilih secara acak secara online dan offline. Analisis data menggunakan analisis faktor eksploratori dan alpha Cronbach. Hasil analisis menunjukkan bahwa School Burnout Inventory versi Bahasa Indonesia, sebagai keseluruhan instrumen maupun sebagai item per item, telah memenuhi kriteria validitas dan reliabilitas yang ditetapkan. Hasil pemfaktoran juga menunjukkan bahwa inventori ini dibentuk oleh dua faktor, di mana Item 1, 3, 4, 7, dan 9 terbentuk dari faktor 1 (kelelahan emosional) dan item 2, 5, 6, dan 8 terbentuk dari faktor 2 (sinisme). Dengan demikian, hasil tersebut mengeliminasi faktor 3 (penurunan pencapaian personal) yang tidak memiliki dukungan empiris yang memadai.
\end{abstract}

Kata Kunci: School Burnout Inventory, burnout akademik, mahasiswa

\section{The validation of School Burnout Inventory-Indonesian version}

\begin{abstract}
Academic burnout can have negative effects on students both academically, personally, and socially. Therefore, early identification of this type of burnout is necessary to prevent further undesirable effects. The School Burnout Inventory is one of the English-language assessment tools to identify the academic burnout of students. The research aims to test the validity and reliability of the Indonesian version of the inventory in the context of the undergraduate program and to investigate its factor structure. The inventory adaptation process is carried out by translating it into Bahasa Indonesia and replacing certain technical terms with other terms that are better suited to the undergraduate context. The translation was evaluated for validity by asking for the judgment of a linguist and a burnout expert. The adapted instrument was then distributed online and offline to research subjects. A total of 542 undergraduate students (126 males and 416 females) were selected at random to participate in the study. Exploratory factor analysis and Cronbach's alpha were used to analyze the research data. The results showed that the School Burnout Inventory, as a whole inventory or as items, is valid and reliable. It was also found that the School Burnout Inventory comprises two factors, which items 1, 3, 4, 7, and 9 are derived from factor 1 (emotional exhaustion), while items 2, 5, 6, and 8 are from factor 2 (cynism). The results further suggest that factor 3 (personal inadequacy) needs to be excluded due to a lack of empirical evidence.
\end{abstract}

Keywords: School Burnout Inventory, academic burnout, undergraduate students

How to Cite: Rahman, D. H. (2020). The validation of school burnout inventory-Indonesian version. Jurnal Penelitian Ilmu Pendidikan, 13(2), 85-93. doi: https://doi.org/10.21831/jpipfip.v13i2.32579.

Received 19-06-2020; Received in revised from 28-06-2020; Accepted 30-06-2020

This is an open-access article under the CC-BY-SA license. 
Jurnal Penelitian Ilmu Pendidikan, 13 (2), 2020 - 86

Rahman

\section{PENDAHULUAN}

Burnout adalah respons individu terhadap tekanan berkepanjangan yang dihadapinya yang ditunjukkan dengan kondisi kejenuhan emosional, hilangnya motivasi, dan berkurangnya komitmen (Schaufeli, 2017). Beberapa literatur dan hasil-hasil penelitian terdahulu menyatakan bahwa burnout ditandai oleh tiga indikator, yaitu: 1) perasaan kelelahan emosional yang luar biasa (emotional exhaution); 2) depersonalisasi dan sinisme (depersonalization and cynism); dan penurunan pencapaian personal (lack of personal accomplishment) (Denton, Chaplin, \& Wall, 2013; Shi, Gugiu, Crowe, \& Way, 2019; Wijegoonewardene, Vidanapathirana, \& Fernando, 2019). Kelelahan emosional dalam hal ini diartikan sebagai ketegangan dan kejenuhan emosional kronis yang disebabkan oleh tekanan yang berlebihan dan terus menerus. Sinisme didefinisikan sebagai sikap acuh dan kehilangan minat terhadap sesuatu yang dianggap sebagai stressor dan orang-orang yang terkait dengan stressor tersebut. Penurunan pencapaian personal berarti berkurangnya perasaan mampu dan penurunan prestasi sebagai akibat dari kelelahan emosional dimaksud. Tiga sindrom ini secara bersama-sama mencirikan individu yang sedang mengalami burnout.

Burnout lazim diukur dalam konteks pekerjaan karena dampaknya yang dianggap sangat merugikan terhadap kinerja karyawan. Namun demikian, burnout juga sangat mungkin terjadi dalam konteks sekolah dan pendidikan formal lainnya. Hal ini karena kadang-kadang para pelajar menerima beban belajar yang cukup berat dan dapat memberikan tekanan pada mereka sebagaimana beban pekerjaan yang dapat menjadi stressor bagi para karyawan atau pelaku dunia kerja lainnya. Hal ini dibuktikan oleh hasil penelitian Salmela-Aro, Kiuru, \& Nurmi (2008) dan Salmela-Aro, Kiuru, Pietikïnen, \& Jokela (2008) yang menemukan fenomena burnout tersebut dalam setting sekolah menengah. Demikian pula, penelitian Rahman, Simon, \& Multisari (2020) dan Shankland et al. (2019) menemukan fenomena burnout dalam setting pendidikan tinggi.

Kondisi burnout diduga dapat menyebabkan berbagai dampak negatif pada para pelajar. Penelitian-penelitian sebelumnya banyak membuktikan bahwa burnout berhubungan dengan berbagai problematika akademik dan perilaku negatif lainnya. Penelitian Duru, Duru, \& Balkis (2014) dan Uludag \& Yaratan (2013) menunjukkan bahwa burnout berhubungan secara negatif dengan prestasi akademik. Dengan kata lain, semakin tinggi burnout seorang pelajar, semakin rendah prestasi yang dicapainya. Bask \& Salmela-Aro (2013) juga menemukan bahwa burnout berhubungan secara positif dengan kecenderungan drop-out para siswa sekolah menengah. Semakin tinggi tingkat burnout siswa, semakin tinggi kemungkinan ia drop-out dari sekolah. Penelitian lainnya juga membuktikan bahwa burnout berhubungan secara negatif dengan keterlibatan dan performansi akademik (Schaufeli, Martinez, Pinto, Salanova, \& Bakker, 2002). Selain permasalahan-permasalahan akademik tersebut, burnout juga diduga berkaitan dengan masalah-masalah perilaku, seperti penggunaan minuman keras (Jackson, Shanafelt, Hasan, Satele, \& Dyrbye, 2016), insomnia (Pagnin et al., 2014), penyalahgunaan Narkoba (Walburg, Moncla, \& Mialhes, 2015), penggunaan internet dan media sosial secara eksesif (Walburg, Mialhes, \& Moncla, 2016), munculnya ide-ide menghabisi diri (Dyrbye et al., 2008), serta permasalahan perilaku lainnya.

Mengingat dampak-dampak negatif tersebut di atas, pengukuran psikologis terhadap burnout di lembaga pendidikan sangat diperlukan dalam rangka identifikasi awal sehingga pihak-pihak terkait (seperti Bimbingan dan Konseling) dapat melakukan tindakan pencegahan atau pengentasan yang diperlukan. Salah satu instrumen yang secara khusus dikembangkan untuk mengukur academic burnout adalah School Burnout Inventory (SBI). Inventori ini memiliki beberapa kelebihan dibandingkan dengan instrumen lain yang sejenis. Salah satunya adalah pada itemnya yang hanya berjumlah sembilan, sehingga efisien untuk diadministrasikan. Kelebihan lain SBI adalah bahwa instrumen ini dikembangkan secara khusus untuk mengukur burnout para pelajar yang disebabkan oleh tugas-tugas akademiknya (Salmela-Aro \& Näätänen, 2005). Hal ini tidak seperti rata-rata alat ukur burnout lainnya yang dikembangkan untuk mengukur burnout dalam setting pekerjaan atau setting umum.

SBI dikembangkan oleh Salmela-Aro \& Näätänen (2005) dengan berdasar pada tiga indikator, yaitu: (1) kelelahan emosional di sekolah, (2) sinisme terhadap makna sekolah, dan (3) perasaan tidak mampu di sekolah. Pada awalnya, instrumen ini terdiri dari 10 item pernyataan (empat item dikembangkan dari indikator 1, tiga item dikembangkan dari indikator 2, dan tiga item dikembangkan dari indikator 3). Setelah melalui pengujian ulang dengan 1418 subjek, diperoleh sembilan item valid 
dan reliabel, sementara satu item yang berasal dari indikator ketiga digugurkan karena tidak memenuhi syarat (Salmela-Aro, Kiuru, Leskinen, \& Nurmi, 2009). Penelitian tersebut juga berhasil mengkonfirmasi bahwa burnout lebih tepat digambarkan dengan tiga indikator daripada dua atau satu indikator.

Perhatian para ahli dan peneliti burnout banyak dicurahkan pada perdebatan tentang jumlah indikator burnout. Perdebatan ini bermula dari hasil penelitian Maslach, Jackson, \& Leiter (1997) yang berhasil mengeliminasi tujuh dari sepuluh indikator dan menyisakan tiga lainnya. Penelitian-penelitian lainnya kemudian bermunculan untuk memastikan apakah tiga indikator tersebut merupakan indikator yang kuat untuk menandakan burnout. Lee \& Ashforth (1993) dan Maslach \& Jackson (1985) menemukan bahwa ketiganya merupakan dimensi-dimensi dari satu faktor yang saling berkorelasi. Adapun Golembiewski \& Munzenrider (1988) menemukan bahwa ketiganya merupakan tiga faktor yang berbeda yang masing-masing dapat membentuk burnout. Koeske \& Koeske (1993) dan Reilly (1994) juga menemukan bahwa ketiganya merupakan faktor yang berbeda, di mana kelelahan emosional merupakan esensi dari burnout. Terakhir, Kalliath, O'Driscoll, Gillespie, \& Bluedorn (2000) menemukan bahwa burnout lebih baik dibentuk oleh dua dimensi, yaitu kelelahan emosional dan depersonalisasi.

Secara logis, menurut Maslach (1993), individu yang mengalami burnout pertama kali akan mengalami kelelahan emosional, kemudian depersonalisasi, dan akhirnya menunjukkan penurunan pencapaian/prestasi. Namun sebaliknya, menurut Golembiewski \& Munzenrider (1988), burnout dimulai dari depersonalisasi yang menyebabkan perasaan tidak mampu berprestasi, dan akhirnya menimbulkan kelelahan emosional. Ahli lainnya, Cordes \& Dougherty (1993) mengatakan bahwa kelelahan emosional dan depersonalisasi merupakan dua dimensi yang saling berhubungan, sementara personal accomplishment merupakan aspek yang berbeda dan berkembang secara paralel (tidak berurutan) dengan kelelahan emosional (Lee \& Ashforth, 1996; Leiter, 1993). Hasil-hasil penelitian menunjukkan bahwa kedua pendapat tersebut juga memiliki landasan yang kuat.

Adaptasi SBI dalam konteks perguruan tinggi memiliki urgensi yang lebih dibandingkan dengan adaptasinya di jenjang pendidikan lainnya. Hal ini karena pendidikan di perguruan tinggi menuntut kemandirian mahasiswa dalam mengatur kegiatan belajar (Ismaniati, Sungkono, \& Wahyuningsih, 2015) dan aktivitas pribadinya (Astuti, 2019) sehingga akan semakin meningkatkan stres individu. Terlebih lagi, jika ia terlibat aktif dalam organisasi kemahasiswaan yang menuntutnya untuk dapat membagi waktu, pikiran, dan tenaga dalam menyelesaikan tugas-tugas akademik dan organisasi sekaligus. Kondisi yang penuh tekanan ini akan semakin meningkatkan potensi terjadinya burnout pada yang bersangkutan. Mengingat sangat diperlukannya instrumen academic burnout yang berbahasa Indonesia, penelitian ini bertujuan untuk menguji validitas dan reliabilitas SBI versi bahasa Indonesia untuk subjek mahasiswa. Selain itu, penelitian ini juga bermaksud menguji apakah sembilan item tersebut betul-betul dibentuk oleh tiga, dua, atau satu faktor sebagaimana masih diperdebatkan oleh para ahli dan peneliti burnout seperti disebutkan di atas.

\section{METODE}

Penelitian ini bertujuan untuk menguji validitas dan reliabilitas SBI versi Bahasa Indonesia, sekaligus menguji jumlah dimensi yang membentuk item-item SBI tersebut. Untuk mencapai tujuan itu, dilakukan prosedur-prosedur: 1) menerjemahkan item-item SBI ke dalam Bahasa Indonesia; 2) melakukan penyesuaian konteks sekolah ke konteks perguruan tinggi; 3) melakukan pengujian ketepatan terjemahan pada satu ahli bahasa dan satu ahli dalam bidang burnout; 4) melakukan pengumpulan data dengan menyebarkan SBI versi Bahasa Indonesia secara online dan offline; 5) melakukan analisis validitas dan reliabilitas; dan 6) melakukan pemfaktoran.

Sampel penelitian ini berjumlah 542 mahasiswa program sarjana di Fakultas Ilmu Pendidikan Universitas Negeri Malang, yang terdiri dari 126 laki-laki dan 416 perempuan. Sampel diperoleh secara acak dengan menyebarkan SBI Versi Bahasa Indonesia secara online dan offline. Berdasarkan semesternya, 181 subjek sedang menempuh semester dua, 190 subjek sedang menempuh semester empat, dan 171 lainnya sedang menempuh semester enam. Berdasarkan keaktifannya di organisasi kemahasiswaan, 220 di antaranya aktif mengikuti 
kegiatan kemahasiswaan, sedangkan 322 lainnya tidak aktif di organisasi apapun. Berdasarkan aktivitas pekerjaan selain kuliah, 89 mahasiswa berkuliah sambil bekerja, sedangkan 453 lainnya hanya berkuliah saja. Berdasarkan jenis pembiayaan kuliahnya, 442 mahasiswa dibiayai oleh orang tua, 95 mahasiswa dibiayai oleh Beasiswa Bidikmisi, dan lima lainnya dibiayai oleh beasiswa lainnya. Adapun berdasarkan tempat tinggalnya, 381 mahasiswa tinggal di kos di sekitar kampus, 122 mahasiswa tinggal bersama orang tua, 15 mahasiswa tinggal di pesantren, dan 24 mahasiswa tinggal di tempat lainnya.

Instrumen yang digunakan dalam penelitian ini adalah School Burnout Inventory (SBI) Versi Bahasa Indonesia. SBI pada awalnya dikembangkan oleh Salmela-Aro \& Näätänen (2005) dengan tujuan untuk mengukur academic burnout pelajar usia remaja. Inventori ini berisi sembilan item yang dikembangkan dari tiga indikator sebagaimana ditampilkan dalam tabel 1. Proses adaptasi dimulai dengan menerjemahkan item-item inventori ke dalam Bahasa Indonesia dan mengganti konteks sekolah ke konteks perguruan tinggi. Selanjutnya, hasil terjemahan tersebut diujikan ketepatannya pada seorang ahli bahasa dan seorang ahli dalam bidang burnout. Masukan kedua ahli tersebut digunakan untuk memperbaiki hasil terjemahan. Secara rinci, kisi-kisi dan hasil adaptasi ditampilkan dalam tabel 1. Pada tahap selanjutnya, SBI digabungkan dengan angket demografis yang berisi pertanyaan tentang jenis kelamin, semester, keaktifan di organisasi kemahasiswaan, aktivitas pekerjaan selain kuliah, jalur masuk kuliah, pembiayaan studi, dan tempat tinggal. SBI versi Bahasa Indonesia tersebut kemudian disebarkan kepada para subjek dalam bentuk instrumen online dan offline.

Tabel 1. Blueprint SBI Versi Bahasa Indonesia

\begin{tabular}{|c|c|c|c|c|}
\hline Indikator & Item Asli & Item Terjemah Bahasa Indonesia & $\begin{array}{l}\text { Item dengan Penyesuaian Konteks } \\
\text { Perkuliahan }\end{array}$ & $\begin{array}{c}\text { Nomor } \\
\text { Item }\end{array}$ \\
\hline \multirow{4}{*}{$\begin{array}{l}\text { Emotional } \\
\text { Exhaution } \\
\text { (Kelelahan } \\
\text { Emosional) }\end{array}$} & $\begin{array}{l}\text { Ifeel overwhelmed by my } \\
\text { schoolwork }\end{array}$ & $\begin{array}{l}\text { Saya merasa kewalahan dengan } \\
\text { tugas-tugas sekolah }\end{array}$ & $\begin{array}{l}\text { Saya merasa kewalahan dengan } \\
\text { tugas-tugas kuliah }\end{array}$ & 1 \\
\hline & $\begin{array}{l}\text { I often sleep badly because of } \\
\text { matters related to my schoolwork }\end{array}$ & $\begin{array}{l}\text { Saya sering tidak nyenyak tidur } \\
\text { karena hal-hal yang berkaitan } \\
\text { dengan tugas-tugas sekolah }\end{array}$ & $\begin{array}{l}\text { Saya sering tidak nyenyak tidur } \\
\text { karena hal-hal yang berkaitan } \\
\text { dengan tugas-tugas kuliah }\end{array}$ & 4 \\
\hline & $\begin{array}{l}\text { I brood over matters related to } \\
\text { my schoolwork a lot during my } \\
\text { free time }\end{array}$ & $\begin{array}{l}\text { Di waktu luang, saya banyak } \\
\text { merenungi hal-hal yang berkaitan } \\
\text { dengan tugas-tugas sekolah }\end{array}$ & $\begin{array}{l}\text { Di waktu luang, saya banyak } \\
\text { merenungi hal-hal yang berkaitan } \\
\text { dengan tugas-tugas kuliah }\end{array}$ & 7 \\
\hline & $\begin{array}{l}\text { The pressure of my schoolwork } \\
\text { causes me problems in my close } \\
\text { relationships with others }\end{array}$ & $\begin{array}{l}\text { Tekanan tugas-tugas sekolah } \\
\text { menyebabkan masalah dalam } \\
\text { hubungan saya dengan orang dekat }\end{array}$ & $\begin{array}{l}\text { Tekanan tugas-tugas kuliah } \\
\text { menyebabkan masalah dalam } \\
\text { hubungan saya dengan orang dekat }\end{array}$ & 9 \\
\hline \multirow{3}{*}{$\begin{array}{l}\text { Cynism } \\
\text { (Sinisme) }\end{array}$} & $\begin{array}{l}\text { Ifeel a lack of motivation in my } \\
\text { schoolwork and often think of } \\
\text { giving up }\end{array}$ & $\begin{array}{l}\text { Saya merasa kurang termotivasi } \\
\text { untuk mengerjakan tugas-tugas } \\
\text { sekolah dan sering berpikir untuk } \\
\text { menyerah }\end{array}$ & $\begin{array}{l}\text { Saya merasa kurang termotivasi } \\
\text { untuk mengerjakan tugas-tugas } \\
\text { kuliah dan sering berpikir untuk } \\
\text { menyerah }\end{array}$ & 2 \\
\hline & $\begin{array}{l}\text { Ifeel that I am losing interest in } \\
\text { my school work }\end{array}$ & $\begin{array}{l}\text { Saya merasa kehilangan minat } \\
\text { dalam menyelesaikan tugas-tugas } \\
\text { sekolah }\end{array}$ & $\begin{array}{l}\text { Saya merasa kehilangan minat } \\
\text { dalam menyelesaikan tugas-tugas } \\
\text { kuliah }\end{array}$ & 5 \\
\hline & $\begin{array}{l}\text { I'm continually wondering wether } \\
\text { my schoolwork has any meaning }\end{array}$ & $\begin{array}{l}\text { Saya terus bertanya-tanya apakah } \\
\text { tugas-tugas sekolah ini ada artinya }\end{array}$ & $\begin{array}{l}\text { Saya terus bertanya-tanya apakah } \\
\text { tugas-tugas kuliah ini ada artinya }\end{array}$ & 6 \\
\hline $\begin{array}{l}\text { Personal } \\
\text { Inadequacy }\end{array}$ & $\begin{array}{l}\text { I often have feelings of } \\
\text { inadequacy in my schoolwork }\end{array}$ & $\begin{array}{l}\text { Saya sering merasa tidak mampu } \\
\text { dalam tugas-tugas sekolah }\end{array}$ & $\begin{array}{l}\text { Saya sering merasa tidak mampu } \\
\text { dalam tugas-tugas kuliah }\end{array}$ & 3 \\
\hline $\begin{array}{l}\text { (Penurunan } \\
\text { Pencapaian } \\
\text { Personal) }\end{array}$ & $\begin{array}{l}\text { I used to have higher expectations } \\
\text { of my schoolwork than I do now }\end{array}$ & $\begin{array}{l}\text { Dulu saya memiliki harapan yang } \\
\text { tinggi terhadap tugas-tugas sekolah, } \\
\text { namun sekarang tidak lagi }\end{array}$ & $\begin{array}{l}\text { Dulu saya memiliki harapan yang } \\
\text { tinggi terhadap tugas-tugas kuliah, } \\
\text { namun sekarang tidak lagi }\end{array}$ & 8 \\
\hline
\end{tabular}

Validitas SBI versi Bahasa Indonesia diuji dengan melihat nilai Kaiser-Meyer-Olkin Measure of Sampling Adequacy (KMO-MSA) pada output KMO and Bartlett's Test yang diperoleh dari analisis faktor eksploratori. Jika nilai KMO-MSA lebih dari 0,5 dengan $p$ kurang dari 0,05, maka, secara umum, SBI dapat dianggap valid dan analisis dapat dilanjutkan ke analisis validitas setiap butir. 
Analisis validitas setiap butir dilakukan dengan melihat nilai Anti-image Correlation pada output Antiimage Matrices yang diperoleh dari analisis faktor eksploratori. Jika nilai Anti-image Correlation lebih besar dari 0,5, maka butir tersebut dapat dianggap valid. Analisis reliabilitas dilakukan dengan Alpha Chronbach dengan kriteria $\geq 0,7$. Dengan kata lain, jika nilai Alpha Chronbach $\geq 0,7$, maka SBI versi Bahasa Indonesia ini dapat dikategorikan sebagai instrumen yang reliabel. Selanjutnya, untuk memastikan jumlah indikator yang membentuk sembilan item SBI, dilakukan pemfaktoran dalam analisis faktor eksploratori. Hal ini dilakukan dengan cara mengekstraksi item-item valid dan reliabel sehingga terbentuk sejumlah faktor tertentu beserta pengelompokan item-item tersebut ke dalam faktor yang tepat. Proses pemfaktoran ini dilakukan dengan metode rotasi orthogonal jenis varimax. Sebuah item akan dianggap mengelompok pada sebuah indikator secara tepat jika ia memiliki nilai loading $\geq$ 0,5 terhadap faktor tersebut.

\section{HASIL DAN PEMBAHASAN}

\section{Hasil}

Analisis faktor eksploratori yang dilakukan pada SBI versi Bahasa Indonesia memperoleh nilai KMO-MSA sebesar 0,868 dengan signifikansi sebesar 0,000. Hal ini berarti bahwa, secara keseluruhan, inventori ini merupakan inventori yang valid. Nilai KMO-MSA tersebut juga telah melampaui nilai minimal untuk melakukan analisis validitas setiap item.

Pengujian validitas selanjutnya dilakukan pada setiap item dengan melihat korelasi antiimage pada output anti-image matrices. Pada tabel 2, diketahui bahwa nilai korelasi antiimage item 1 adalah sebesar 862, item 2 sebesar 852, item 3 sebesar 882, item 4 sebesar 851, item 5 sebesar 852, item 6 sebesar 887, item 7 sebesar 870, item 8 sebesar 852, dan item 9 sebesar 927. Berdasarkan nilai-nilai tersebut, seluruh item memiliki loading factor lebih besar dari 0,50 sehingga dapat ditafsirkan bahwa kesembilan item tersebut merupakan item yang valid.

Tabel 2. Output Anti-image Matrices

\begin{tabular}{llrrrrrrrrr}
\hline & & Item 1 & Item 2 & Item 3 & Item 4 & Item 5 & Item 6 & Item 7 & Item 8 & Item 9 \\
\hline Kovarians & Item 1 & 0,597 & $-0,185$ & $-0,094$ & $-0,117$ & 0,022 & $-0,030$ & $-0,027$ & $-0,009$ & $-0,079$ \\
Anti-image & Item 2 & $-0,185$ & 0,477 & $-0,160$ & 0,037 & $-0,103$ & $-0,045$ & $-0,024$ & $-0,036$ & $-0,041$ \\
& Item 3 & $-0,094$ & $-0,160$ & 0,606 & $-0,108$ & $-0,073$ & $-0,027$ & 0,009 & 0,028 & $-0,024$ \\
& Item 4 & $-0,117$ & 0,037 & $-0,108$ & 0,747 & $-0,040$ & 0,042 & $-0,151$ & $-0,041$ & $-0,117$ \\
& Item 5 & 0,022 & $-0,103$ & $-0,073$ & $-0,040$ & 0,459 & $-0,125$ & 0,001 & $-0,191$ & $-0,071$ \\
& Item 6 & $-0,030$ & $-0,045$ & $-0,027$ & 0,042 & $-0,125$ & 0,625 & $-0,103$ & $-0,142$ & $-0,015$ \\
& Item 7 & $-0,027$ & $-0,024$ & 0,009 & $-0,151$ & 0,001 & $-0,103$ & 0,868 & $-0,002$ & $-0,046$ \\
& Item 8 & $-0,009$ & $-0,036$ & 0,028 & $-0,041$ & $-0,191$ & $-0,142$ & $-0,002$ & 0,549 & $-0,069$ \\
& Item 9 & $-0,079$ & $-0,041$ & $-0,024$ & $-0,117$ & $-0,071$ & $-0,015$ & $-0,046$ & $-0,069$ & 0,717 \\
Korelasi & Item 1 & $0,862^{\mathrm{a}}$ & $-0,347$ & $-0,157$ & $-0,175$ & 0,043 & $-0,049$ & $-0,037$ & $-0,016$ & $-0,122$ \\
Anti-image & Item 2 & $-0,347$ & $0,852^{\mathrm{a}}$ & $-0,298$ & 0,061 & $-0,220$ & $-0,082$ & $-0,037$ & $-0,070$ & $-0,070$ \\
& Item 3 & $-0,157$ & $-0,298$ & $0,882^{\mathrm{a}}$ & $-0,160$ & $-0,138$ & $-0,044$ & 0,013 & 0,049 & $-0,037$ \\
& Item 4 & $-0,175$ & 0,061 & $-0,160$ & $0,851^{\mathrm{a}}$ & $-0,068$ & 0,062 & $-0,187$ & $-0,065$ & $-0,160$ \\
& Item 5 & 0,043 & $-0,220$ & $-0,138$ & $-0,068$ & $0,852^{\mathrm{a}}$ & $-0,233$ & 0,002 & $-0,380$ & $-0,123$ \\
& Item 6 & $-0,049$ & $-0,082$ & $-0,044$ & 0,062 & $-0,233$ & $0,887^{\mathrm{a}}$ & $-0,140$ & $-0,242$ & $-0,022$ \\
& Item 7 & $-0,037$ & $-0,037$ & 0,013 & $-0,187$ & 0,002 & $-0,140$ & $0,870^{\mathrm{a}}$ & $-0,003$ & $-0,059$ \\
& Item 8 & $-0,016$ & $-0,070$ & 0,049 & $-0,065$ & $-0,380$ & $-0,242$ & $-0,003$ & $0,852^{\mathrm{a}}$ & $-0,109$ \\
& Item 9 & $-0,122$ & $-0,070$ & $-0,037$ & $-0,160$ & $-0,123$ & $-0,022$ & $-0,059$ & $-0,109$ & $0,927^{\mathrm{a}}$ \\
\hline
\end{tabular}

Sumber: Data primer yang diolah, 2020

Setelah diperoleh item-item yang valid seperti disebutkan di atas, instrumen tersebut kemudian diuji reliabilitasnya dengan Alpha Cronbach. Hasil pengujian memperoleh nilai Alpha Cronbach sebesar 0,831. Dengan demikian, dapat diinterpretasikan bahwa, secara keseluruhan, inventori ini merupakan inventori yang reliabel. Selanjutnya, dilakukan pengujian reliabilitas setiap item dengan melihat output Item-Total Statistics. Seperti ditampilkan pada tabel 3, diperoleh nilai Alpha Cronbach item 1 sebesar 0,812, item 2 sebesar 0,800, item 3 sebesar 0,811, item 4 sebesar 0,826, item 5 sebesar 0,798 , item 6 sebesar 0,813 , item 7 sebesar 0,835 , item 8 sebesar 0,808 , dan item 9 sebesar 0,816. Berdasarkan nilai-nilai tersebut, diketahui bahwa seluruh item memiliki nilai Alpha Cronbach lebih dari 0,70 sehingga dapat ditafsirkan bahwa kesembilan item SBI versi Bahasa Indonesia ini merupakan item yang reliabel. 
Jurnal Penelitian Ilmu Pendidikan, 13 (2), 2020 - 90

Rahman

Tabel 3. Output Item-Total Statistics

\begin{tabular}{crrrr}
\hline & $\begin{array}{c}\text { Scale Mean if } \\
\text { Item Deleted }\end{array}$ & $\begin{array}{c}\text { Scale Variance } \\
\text { if Item Deleted }\end{array}$ & $\begin{array}{c}\text { Corrected Item- } \\
\text { Total Correlation }\end{array}$ & $\begin{array}{c}\text { Cronbach's Alpha } \\
\text { if Item Deleted }\end{array}$ \\
\hline Item 1 & 16,97 & 49,363 & 0,571 & 0,812 \\
Item 2 & 17,79 & 45,678 & 0,652 & 0,800 \\
Item 3 & 17,91 & 48,605 & 0,566 & 0,811 \\
Item 4 & 17,17 & 47,233 & 0,446 & 0,826 \\
Item 5 & 18,48 & 45,518 & 0,675 & 0,798 \\
Item 6 & 17,84 & 45,801 & 0,543 & 0,813 \\
Item 7 & 16,72 & 51,604 & 0,331 & 0,835 \\
Item 8 & 18,29 & 47,384 & 0,589 & 0,808 \\
Item 9 & 18,33 & 46,461 & 0,521 & 0,816 \\
\hline Sumber: Data primer yang diolah, 2020
\end{tabular}

Pemfaktoran dengan metode rotasi orthogonal jenis varimax berhasil mengelompokkan sembilan item SBI ke dalam dua kelompok faktor. Item 2, 5, 6, dan 8 mengelompok dalam faktor 1, sementara item 1, 3, 4, 7, dan 9 mengelompok dalam faktor 2. Dengan demikian, hasil ini mengonfirmasi bahwa academic burnout lebih tepat untuk dibentuk oleh dua faktor daripada tiga faktor yang diajukan oleh pengembang SBI versi Bahasa Inggris. Berdasarkan pengelompokan itemitem ini, dapat dirumuskan bahwa faktor 1 adalah sinisme (cynism), sementara faktor 2 adalah kelelahan emosional (emotional exhaution). Secara lengkap, pengelompokan item-item beserta nilai loading factor-nya ditampilkan dalam tabel 4.

\begin{tabular}{lcc}
\multicolumn{2}{c}{ Tabel 4. Output Rotated Component Matrix } \\
\cline { 2 - 3 } & \multicolumn{2}{c}{ Faktor } \\
\cline { 2 - 3 } & 0,323 & 2 \\
\hline Loading Factor Item 1 & 0,589 & 0,672 \\
Loading Factor Item 2 & 0,402 & 0,506 \\
Loading Factor Item 3 & 0,066 & 0,585 \\
Loading Factor Item 4 & 0,809 & 0,264 \\
Loading Factor Item 5 & 0,777 & 0,124 \\
Loading Factor Item 6 & 0,062 & 0,554 \\
Loading Factor Item 7 & 0,809 & 0,142 \\
Loading Factor Item 8 & 0,399 & 0,504 \\
Loading Factor Item 9 & \multicolumn{3}{l}{}
\end{tabular}

Sumber: Data primer yang diolah, 2020

Berdasarkan nilai loading factor setiap item yang ditampilkan dalam tabel 4, faktor 3 (penurunan pencapaian personal) dieliminasi karena item-item yang dikembangkan darinya (item 3 dan 8) terekstraksi ke faktor 2 dan 1, serta tidak ada satupun item-item lainnya yang mengelompok dalam faktor ini.

\section{Pembahasan}

Tujuan utama penelitian ini adalah untuk mengetahui validitas dan reliabilitas SBI versi Bahasa Indonesia dalam konteks pendidikan sarjana. Hasil penelitian menunjukkan bahwa inventori ini, baik secara keseluruhan maupun masing-masing item, memiliki validitas dan reliabilitas yang baik. Hasil ini mengkonfirmasi hasil penelitian Rahman et al. (2020) yang menemukan bahwa SBI versi Bahasa Indonesia memiliki validitas dan reliabilitas yang baik. Hanya saja, SBI versi tersebut diadaptasi dalam konteks pendidikan profesi guru dan diuji dengan jumlah subjek yang terbatas. Karena itu, penelitian ini telah menutup kelemahan penelitian Rahman et al. (2020) tersebut dengan menggunakan jumlah subjek yang lebih memadai. Hasil ini juga memperkuat kesimpulan Salmela-Aro et al. (2009) dan Salmela-Aro \& Näätänen (2005) bahwa instrumen yang mereka kembangkan ini memiliki kelayakan psikometris yang memadai.

Salah satu hasil penting penelitian ini adalah terekstraksinya item-item SBI ke dalam dua faktor. Hal ini berarti bahwa hasil penelitian ini memperkuat pendapat bahwa burnout dapat dijelaskan oleh dua faktor dan menentang pendapat yang menyatakan bahwa burnout dijelaskan oleh tiga faktor. SBI sendiri sebenarnya dikembangkan dengan berdasar pada tiga faktor (Salmela-Aro \& Näätänen, 2005). Demikian pula, pengujian SBI berikutnya oleh Salmela-Aro et al. (2009) juga mendukung pendapat tiga faktor dengan tambahan eliminasi beberapa item. Terdapat dua hipotesis yang mungkin dapat dibangun dari perbedaan hasil pemfaktoran tersebut. Hipotesis pertama adalah perbedaan budaya 
menyebabkan perbedaan jumlah faktor yang membentuk burnout. Seperti diketahui, SBI versi asli dikembangkan dan diujicobakan dalam budaya Finlandia, sementara SBI dalam penelitian ini diadaptasi dan diujicobakan dalam budaya Indonesia. Hipotesis kedua adalah perbedaan konteks penelitian yang menyebabkan perbedaan jumlah faktor tersebut. SBI versi asli dikembangkan dan diujicobakan dalam konteks sekolah, sementara SBI dalam penelitian ini diadaptasi dan diujicobakan dalam konteks perguruan tinggi. Dengan kata lain, konteks budaya Indonesia dan perguruan tinggi tidak menganggap penurunan prestasi sebagai indikator burnout. Tentu saja, pembuktian hipotesis ini masih memerlukan penelitian-penelitian lanjutan lainnya.

Dalam penelitian ini, item 3 (Saya sering merasa tidak mampu dalam tugas-tugas kuliah) mengelompok ke dalam faktor kelelahan emosional, sedangkan item 8 (Dulu saya memiliki harapan yang tinggi terhadap tugas-tugas kuliah, namun sekarang tidak lagi) mengelompok ke dalam faktor sinisme. Bila dicermati dengan seksama, pengelompokan kedua item tersebut ke dalam dua faktor yang telah disebutkan terlihat sangat tepat. Seseorang yang lelah secara emosional akan merasa tidak mampu menyelesaikan tugas-tugas (item 3), sebagaimana ia juga merasa kewalahan dengan tugastugas tersebut (item 1), tidak nyenyak tidur (item 4), dan menyebabkan masalah dalam hubungan dengan orang dekat (item 9). Demikian pula, sinisme pada stressor dapat digambarkan dengan kehilangan harapan terhadap manfaat tugas-tugas kuliah (item 8), sebagaimana ia kurang termotivasi untuk mengerjakan tugas-tugas kuliah (item 2) dan kehilangan minat dalam menyelesaikan tugas-tugas kuliah (item 5).

Terkait dengan jumlah faktor pembentuk burnout seperti dibahas di atas, penelitian-penelitian sebelumnya menemukan hasil yang bervariasi. Lee \& Ashforth (1993) dan Maslach \& Jackson (1985) menemukan bahwa ketiga faktor merupakan dimensi-dimensi dari satu faktor yang saling berkorelasi. Adapun Golembiewski \& Munzenrider (1988) menemukan bahwa ketiganya merupakan tiga faktor yang berbeda yang masing-masing dapat membentuk burnout. Namun demikian, penelitian lainnya oleh Kalliath et al. (2000), Yadama \& Drake (1995), Koeske \& Koeske (1993), dan Byrne (1991) justru menemukan bahwa burnout dibentuk hanya oleh dua faktor, sebagaimana juga temuan penelitian ini. Rata-rata hasil penelitian yang mendukung dua faktor menemukan bahwa Penurunan Pencapaian Personal (personal inadequacy) merupakan faktor yang bermasalah yang menjadi penyebab perbedaan pendapat ini. Bahkan, Cordes \& Dougherty (1993) dalam metaanalisisnya menyatakan bahwa Penurunan Pencapaian Personal adalah variabel yang lain yang berkembang secara paralel bersama kelelahan emosional. Lebih lanjut, Kalliath et al. (2000), Lee \& Ashforth (1996), dan Reilly (1994) menyatakan bahwa Kelelahan Emosional adalah elemen pokok burnout, sedangkan Sinisme adalah elemen sekundernya.

Penelitian ini memiliki beberapa kelemahan yang perlu diperhatikan. Salah satu kelemahan tersebut adalah sampel yang berasal dari satu fakultas. Hal ini membuat generabilitas hasil penelitian menjadi sangat terbatas. Kelemahan lainnya adalah pada proses pengalihbahasaan item-item instrumen. Seperti telah dijelaskan di atas, pengujian bahasa terhadap item-item yang telah diIndonesiakan-kan hanya dilakukan oleh satu ahli bahasa. Hal ini menyebabkan kemungkinan subjektivitas hasil penilaian yang sangat tinggi karena tidak adanya penilai pembanding. Kelemahankelemahan ini diharapkan dapat disempurnakan dalam penelitian-penelitian selanjutnya.

\section{PENUTUP}

Merujuk pada hasil dan pembahasan di atas, dapat disimpulkan bahwa, secara keseluruhan, SBI versi Bahasa Indonesia ini adalah instrumen yang valid dan reliabel. Demikian pula, kesembilan item SBI tersebut adalah item-item yang memenuhi kriteria validitas dan reliabilitas. Pemfaktoran dengan analisis faktor eksploratori berhasil mengelompokkan item-item SBI ini ke dalam dua kelompok faktor. Item 1, 3, 4, 7, dan 9 mengelompok ke dalam faktor kelelahan emosional, sedangkan item 2, 5, 6, dan 8 mengelompok ke dalam faktor sinisme.

Penelitian ini memiliki dua kelemahan yang perlu disadari oleh pengguna hasil penelitian. Kelemahan pertama adalah pada homogenitas sampel sehingga membatasasi generabilitas hasil penelitian. Kelemahan kedua adalah pada proses pengujian alih bahasa instrumen yang hanya melibatkan seorang ahli bahasa dan seorang ahli burnout. Dengan keadaan ini, hasil pengujian kurang aman dari subjektivitas para penguji. 
Jurnal Penelitian Ilmu Pendidikan, 13 (2), 2020 - 92

Rahman

\section{DAFTAR PUSTAKA}

Astuti, B. (2019). Profil kemandirian belajar mahasiswa Bimbingan dan Konseling. Jurnal Penelitian Ilmu Pendidikan, 12(1), 63-74. Doi:https://doi.org/10.21831/jpipfip.v12i1.24327.

Bask, M., \& Salmela-Aro, K. (2013). Burned out to drop out: Exploring the relationship between school burnout and school dropout. European Journal of Psychology of Education, 28(2), 511528.

Byrne, B. M. (1991). The maslach burnout inventory: Validating factorial structure and invariance across intermediate, secondary, and university educators. Multivariate Behav Res, 26(4), 583605. doi:10.1207/s15327906mbr2604_2.

Cordes, C. L., \& Dougherty, T. W. (1993). A review and an integration of research on job burnout. Academy of $\quad$ Management 18(4), 621-656. Doi:https://doi.org/10.5465/amr.1993.9402210153.

Denton, E. G., Chaplin, W. F., \& Wall, M. (2013). Teacher burnout: A comparison of two cultures using confirmatory factor and item response models. International Journal of Quantitative Research in Education, 1(2), 147.

Duru, E., Duru, S., \& Balkis, M. (2014). Analysis of relationships among burnout, academic achievement, and self-regulation. Educational Sciences: Theory and Practice, 14(4), 12741284.

Dyrbye, L. N., Thomas, M. R., Massie, F. S., Power, D. V., Eacker, A., Harper, W., \& Shanafelt, T. D. (2008). Burnout and suicidal ideation among U.S. medical students. Annals of Internal Medicine, 149(5), 334-341. Doi:https://doi.org/10.7326/0003-4819-149-5-200809020-00008.

Golembiewski, R. T., \& Munzenrider, R. F. (1988). Phases of burnout: Developments in concepts and applications. New York: Praeger Publishers.

Ismaniati, C., Sungkono, S., \& Wahyuningsih, D. (2015). Model blended learning untuk meningkatkan kemandirian belajar dan daya tarik dalam perkuliahan. Jurnal Penelitian Ilmu Pendidikan, 8(2), 19-27. Doi:https://doi.org/10.21831/jpipfip.v8i2.8269.

Jackson, E. R., Shanafelt, T. D., Hasan, O., Satele, D. V., \& Dyrbye, L. N. (2016). Burnout and alcohol abuse/dependence among US medical students. Academic Medicine, 91(9), 1251-1256. Doi:https://doi.org/10.1097/ACM.0000000000001138.

Kalliath, T. J., O'Driscoll, M. P., Gillespie, D. F., \& Bluedorn, A. C. (2000). A test of the maslach burnout inventory in three samples of healthcare professionals. Work \& Stress, 14(1), 35-50. Doi:https://doi.org/10.1080/026783700417212.

Koeske, G. F., \& Koeske, R. D. (1993). A preliminary test of a stress-strain-outcome model for reconceptualizing the burnout phenomenon. Journal of Social Service Research, 17(3-4), 107135. Doi:https://doi.org/10.1300/J079v17n03_06.

Lee, R. T., \& Ashforth, B. E. (1993). A further examination of managerial burnout: Toward an integrated model. Journal of Organizational Behavior, 19(1), 3-20. Doi:https://doi.org/10.1002/job.4030140103.

Lee, R. T., \& Ashforth, B. E. (1996). A meta-analytic examination of the correlates of the three dimensions of job burnout. Journal of Applied Psychology, 81(2), 123-133.

Leiter, M. P. (1993). Burnout as a developmental process: consideration of models. In W. B. Schaufeli, C. Maslach, \& T. Marek (Eds.), Professional Burnout: Recent Developments in Theory and Research (pp. 237-250). Washington, DC: Taylor \& Francis.

Maslach, C. (1993). Burnout: A multidimensional perspective. In W. B. Schaufeli, C. Maslach, \& T. Marek (Eds.), Professional Burnout: Recent Developments in Theory and Research (pp. 19-32). Washington, DC: Taylor \& Francis.

Maslach, C., \& Jackson, S. E. (1985). The role of sex and family variables in burnout. Sex Roles, 12(78), 837-851.

Maslach, C., Jackson, S. E., \& Leiter, M. P. (1997). Maslach burnout inventory. In C. P. Zalaquett \& R. J. Wood (Eds.), Evaluating Stress: A Book of Resources (pp. 191-218). Lanham, MD: Scarecrow Education.

Pagnin, D., de Queiroz, V., Carvalho, Y. T., Dutra, A. S., Amaral, M. B., \& Queiroz, T. T. (2014). The relation between burnout and sleep disorders in medical students. Academic Psychiatry, 38(4), 438-444. Doi:https://doi.org/10.1007/s40596-014-0093-z. 
Rahman, D. H., Simon, I. M., \& Multisari, W. (2020). Burnout akademik guru peserta pendidikan profesi. Jurnal Konseling Andi Matappa, 4(1), 10-17. Doi:10.31100/jurkam.v4i1.520.

Reilly, N. (1994). Exploring a paradox: Commitment as a moderator of the stressor-burnout relationship. Journal of Applied Social Psychology, 24(5), 397-414. Doi:https://doi.org/10.1111/j.1559-1816.1994.tb00589.x

Salmela-Aro, K., Kiuru, N., Leskinen, E., \& Nurmi, J. E. (2009). School burnout inventory (SBI) reliability and validity. European Journal of Psychological Assessment, 25(1), 48-57.

Salmela-Aro, K., Kiuru, N., \& Nurmi, J. E. (2008). The role of educational track in adolescents' school burnout: A longitudinal study. The British Psychological Society, 78(4), 663-689. Doi:https://doi.org/10.1348/000709908X281628.

Salmela-Aro, K., Kiuru, N., Pietikïnen, M., \& Jokela, J. (2008). Does school matter? The role of school context in adolescents' school-related burnout. European Psychologist, 13(1), 12-23.

Salmela-Aro, K., \& Näätänen, P. (2005). BBI-10. Nuorten koulu-uupumusmenetelmä [Method of assessing adolescents' school burnout]. Helsinki: Edita.

Schaufeli, W. B. (2017). Burnout: A short socio-cultural history. In S. Neckel, A. K. Schaffner, \& G. Wagner (Eds.), Burnout, Fatigue, Exhaustion: An Interdisciplinary Perspectives on a Modern Affliction (pp. 105-128). Gewerbestrasse, Switzerland: Springer.

Schaufeli, W. B., Martinez, I. M., Pinto, A. M., Salanova, M., \& Bakker, A. B. (2002). Burnout and engagement in university students: A cross-national study. Journal of Cross-Cultural Psychology, 33(5), 464-481. Doi:https://doi.org/10.1177/0022022102033005003.

Shankland, R., Kotsou, I., Vallet, F., Bouteyre, E., Dantzer, C., \& Leys, C. (2019). Burnout in university students: The mediating role of sense of coherence on the relationship between daily hassles and burnout. Higher Education, 78(1), 91-113.

Shi, Y., Gugiu, P. C., Crowe, R. P., \& Way, D. P. (2019). A rasch analysis validation of the maslach burnout inventory-student survey with preclinical medical students. Teaching and Learning in Medicine, 31(2), 154-169. Doi:https://doi.org/10.1080/10401334.2018.1523010

Uludag, O., \& Yaratan, H. (2013). The effects of justice and burnout on achievement: An empirical investigation of university students. Croatian Journal of Education, 15(2), 97-116.

Walburg, V., Mialhes, A., \& Moncla, D. (2016). Does school-related burnout influence problematic facebook use? Children and Youth Services Review, 61, 327-331. Doi:https://doi.org/10.1016/j.childyouth.2016.01.009.

Walburg, V., Moncla, D., \& Mialhes, A. (2015). Burnout among high-school students and cannabis use, consumption frequencies, abuse and dependence. Child \& Youth Care Forum, 44(1), 33-42.

Wijegoonewardene, N., Vidanapathirana, J., \& Fernando, T. (2019). Validation of the maslach burnout inventory-human services survey to assess burnout of prison afficers working in Sri Lankan prisons. Journal of the College of Community Physicians of Sri Lanka, 25(1), 15-22.

Yadama, G. N., \& Drake, B. (1995). Confirmatory factor analysis of the maslach burnout inventory. Social Work Research, 19, 184-192. 